\title{
Ectopia renal: simple y cruzada con fusión
}

\author{
Martínez-Rodríguez RH, Rodríguez Escovar FP, Esquena S, Sánchez-Martín F, \\ Millán Rodríguez F, Villavicencio Mavrich H. \\ Servicio de Urología. Fundació Puigvert. Barcelona.
}

Actas Urol Esp. 2007;31(3):297

$\mathrm{L}$ a ectopia renal es el resultado de una anomalía de la migración hacia la fosa renal de la ampolla ureteral y del blastema metanéfrico. La localización puede ser torácica, iliaca, pélvica y/o cruzada, con o sin fusión con la unidad renal contralateral. La ectopia congénita simple (Fig. 1) se refiere a un riñón bajo (frecuentemente pélvico) en el lado que no completó su ascenso. La vascularización en estos casos procede de vasos adyacentes y el uréter es corto a diferencia de la nefroptosis o ectopia adquirida. La prevalencia es de 8-11 casos cada 10.000 nacidos vivos y su incidencia es de 1:900, sin diferencias respecto al sexo. De curso habitualmente asintomático, la aparición de infecciones de repetición o de clíni-

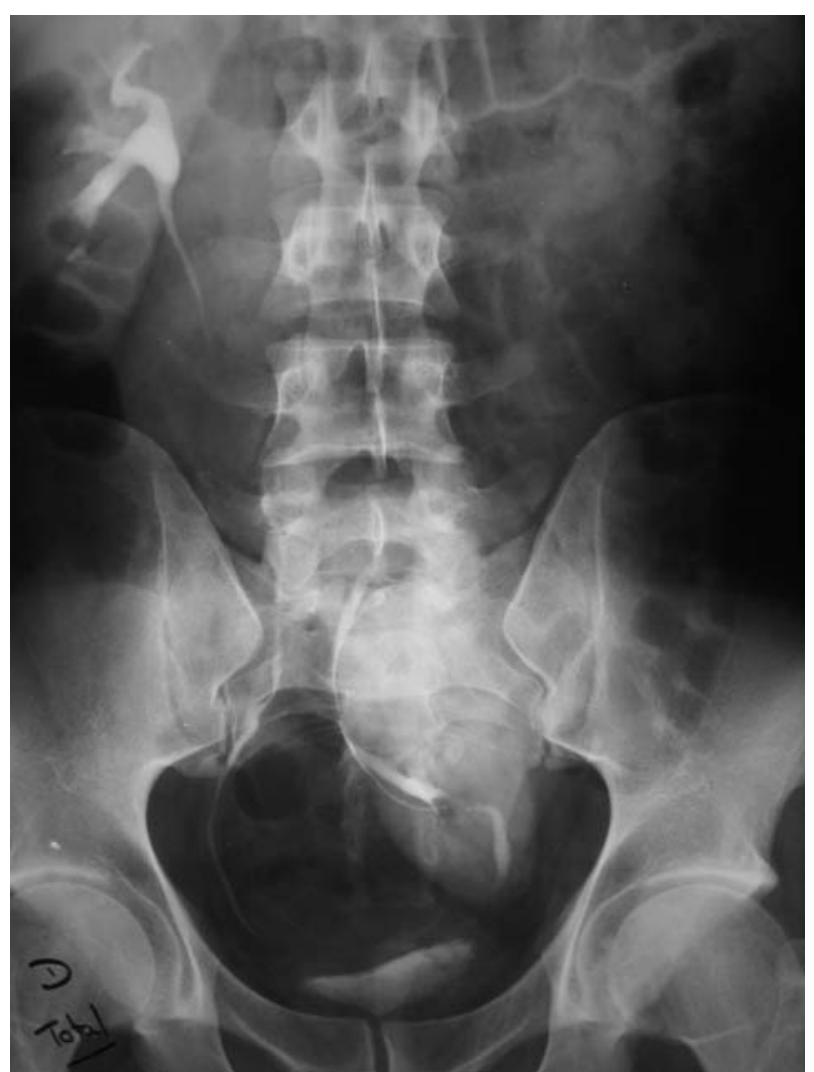

FIGURA 1. Ectopia renal simple. ca de uropatía obstructiva puede conducir a su hallazgo casual durante exploraciones radiológicas rutinarias.

Por otro lado, durante el desarrollo embriológico, el esbozo renal y ureteral pueden cruzar la línea media originando una ectopia renal cruzada, que puede acompañarse o no de fusión renal contralateral, sin que esta situación traduzca una relevancia clínica especial (Fig. 2).

Correspondencia autor: R. Martínez Rodríguez.

Servicio de Urología. Fundació Puigvert. Cartagena, 340-360 08025 Barcelona. Tel.: 934169700

E-mail autor: hugomar2@yahoo.es

Información artículo: Imágenes en Urología

Trabajo recibido: febrero 2006

Trabajo aceptado: marzo 2006

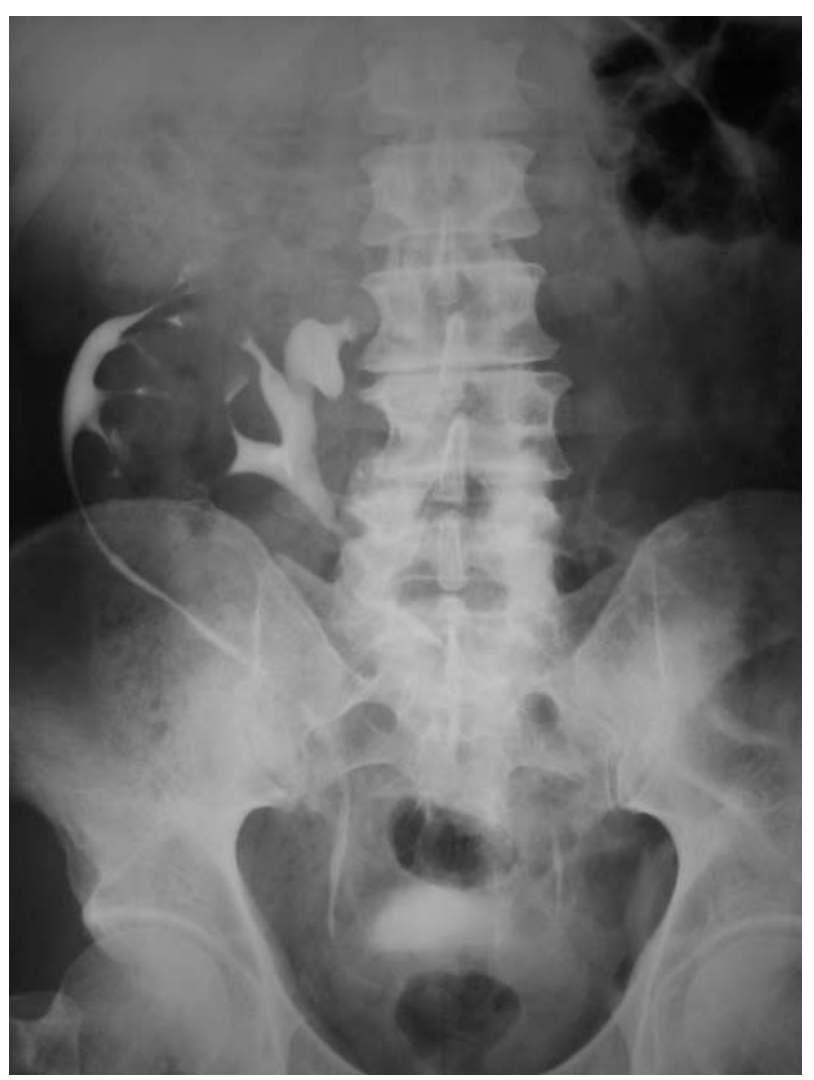

FIGURA 2. Ectopia renal cruzada con fusión. 